DOI: 10.17951/lrp. 2017.36.4.133

\author{
WOJCIECH CZERSKi \\ Uniwersytet Marii Curie-Skłodowskiej \\ EdyTa Gonciarz
}

Stowarzyszenie Katolicki Ruch Antynarkotyczny KARAN w Radomiu filia Bogucin

\title{
RYZYKO UZALEŻNIENIA STUDENTÓW OD MEDIÓW SPOŁECZNOŚCIOWYCH NA PRZYKŁADZIE FACEBOOKA
}

\begin{abstract}
Streszczenie: Niniejsze opracowanie jest poświęcone zagadnieniu uzależnienia behawioralnego związanego z mediami społecznościowymi. Pierwsza część opisuje fenomen, jakim są portale społecznościowe. Wyjaśnione zostały również pojęcia uzależnienia oraz uzależnienia behawioralnego na przykładzie Facebooka. Druga część prezentuje wyniki badań ankietowych, których celem była diagnoza ryzyka uzależnienia od Facebooka. Z zaprezentowanych wyników widać, że jedynie kilku badanych studentów może być uzależnionym od tego portalu społecznościowego.
\end{abstract}

Słowa kluczowe: uzależnienie, Facebook, media społecznościowe, uzależnienia behawioralne

\section{FENOMEN MEDIÓW SPOŁECZNOŚCIOWYCH}

Zarówno w literaturze, jak i słownikach znaleźć można wiele definicji pojęcia media społecznościowe. Justyna Strykowska jako media społecznościowe traktuje wszelkie kanały komunikacyjne, „które umożliwiają interakcję między internautami za pomocą technologii internetowych" (Strykowska 2012, s. 321). Według internetowego wydania oksfordzkiego słownika języka angielskiego termin ten również rozumieć należy jako „strony internetowe i aplikacje umożliwiające użytkownikom tworzenie i udostępnianie zawartości albo uczestniczenie w sieciach społecznościowych" (www 1). Ivy Wigmore twierdzi natomiast, że social media (czyli media społecznościowe) to „zbiorowe kanały komunikacji online poświęcone społeczności otwartej i oparte na wejściu, interakcji, dzieleniu się treścią oraz współpracy" (www 2). 
Analizując powyższe definicje mediów społecznościowych, można zauważyć, że „są one nową formą aktywności w sieci, opierającą się na tym, iż użytkownicy Internetu nie są tylko odbiorcami przekazu, ale także ich pełnoprawnymi twórcami” (Kowalska 2013, s. 207). Katarzyna Fabianiak-Czerniak (2012, s. 184) twierdzi, podobnie jak Paweł Tomczuk, że social media to środki przekazu „podlegające społecznej kontroli [...], które mogą być wykorzystane na dowolną skalę”. Karolina Łopacińska (2004, s. 3) zauważa również, że media społecznościowe „powstały z technologii i mediów mieszanego pochodzenia, z wykorzystaniem formatów multimedialnych i licznych platform dostawczych, które gwarantowały globalny zasięg i umożliwiają natychmiastową komunikację w czasie rzeczywistym”.

Patrząc na powyższe rozważania, nie sposób nie dojść do wniosku, że gdyby nie dynamiczny rozwój technologii internetowych oraz wykorzystywanie przez użytkowników różnych form multimedialnych do przekazywania informacji, zapewne media społecznościowe nie odgrywałyby tak znaczącej roli w naszym życiu. Spowodowane jest to oczywiście potrzebą każdego człowieka do tworzenia relacji z ludźmi, a media społecznościowe w pełni ją zaspokajają. Jak podkreśla Strykowska (2012, s. 322), „współczesność nazywana jest »wiekiem komunikacji»”. Współczesne społeczeństwo wykazuje gwałtownie rosnącą potrzebę dzielenia się sobą z innymi - zarówno informacjami, jak i zdjęciami, ale wyłącznie przez Internet. Dostęp do tego typu zasobów sieciowych w czasie rzeczywistym powoduje złudne zachowanie więzi społecznych.

Wśród typowych mediów społecznościowych wyróżnić można blogi czy też sieci społecznościowe. Blogi to pewien rodzaj stron internetowych zawierających chronologicznie ustawione wpisy autora, mogą być wzbogacone różnymi formami multimedialnymi, które inni użytkownicy mogą komentować i przez to wpływać na ich treść. Wielu autorów twierdzi, że jest to jeden ze sposobów komunikacji (Doctorow i inni 2003).

Sieci społecznościowe natomiast to „sieci społecznych interakcji i związków osobistych, a także należące do poszczególnych osób strony internetowe lub inne aplikacje, które pozwalają użytkownikom na komunikowanie się ze sobą poprzez umieszczanie informacji, komentarzy, wiadomości, obrazów itp." (www 3).

Danah M. Boyd i Nicole B. Ellison (2007, s. 211) traktują sieci społecznościowe jako:

serwisy internetowe umożliwiające jednostkom:

1. konstruowanie publicznych lub semi-publicznych profili,

2. utworzenie listy innych użytkowników, z którymi są powiązani,

3. oglądanie własnej listy powiązań i tych stworzonych przez innych użytkowników.

Martyna Kotyśko oraz jej zespół (2014, s. 178) uważają sieci społecznościowe za wynalazek XXI wieku. Ich zdaniem zrewolucjonizowały one kontakty międzyludz- 
kie. Stało się to dzięki temu, że „za ich pomocą można porozumiewać się z ludźmi bez względu na czas i miejsce pobytu, a do tego celu wystarczy jedynie łącze internetowe".

Sieci społecznościowe, takie jak Facebook czy Twitter, powstały jako „współczesna odpowiedź cyfrowego świata na pierwotną potrzebę człowieka poszukiwania kontaktu $\mathrm{z}$ drugim człowiekiem, potrzebę łączenia się w grupy społeczne" (Strykowska 2012, s. 327).

Zbyszko Melosik (2013, s. 99), prowadząc rozważania na temat wpływu Facebooka na człowieka, zauważa, że pozwala on „na podtrzymanie relacji z osobami, z którymi nie ma możliwości interakcji w rzeczywistości oraz daje poczucie wsparcia społecznego". Dodaje również, iż portale społecznościowe umożliwiają ich użytkownikom pewnego rodzaju zaspokojenie potrzeby, którą określa się jako psychologiczny status bycia członkiem społeczności.

Historia portali społecznościowych sięga lat 90. XX wieku, kiedy to powstał portal SixDegrees.com. Nie cieszył się on jednak zbyt dużym zainteresowaniem, więc zakończono jego działanie w 2002 roku. Dopiero wiele lat później powstały obecne potęgi, takie jak LinkedIn, MySpace, YouTube, Twitter czy w końcu Facebook. Jeden z bardziej popularnych portali społecznościowych w Polsce Nasza-Klasa.pl uruchomiona została dopiero w 2006 roku.

Nasza-Klasa.pl była popularna wśród polskich użytkowników Internetu do momentu pojawienia się polskiej wersji językowej Facebooka, czyli do 2008 roku. Wtedy właśnie amerykański portal stawał się liderem nie tylko u nas w kraju, ale i prawie na całym świecie. Obecnie Facebook ma ponad miliard użytkowników, a w Polsce jest ich blisko 4,5 miliona (co stanowi 35\% użytkowników wszystkich portali społecznościowych dostępnych przez Polaków).

Pierwotne założenia zarówno Facebooka, jak i rodzimej Naszej Klasy były inne od obecnych. Celem ich istnienia było przede wszystkim umożliwienie kontaktu głównie $\mathrm{z}$ rodziną, znajomymi, kolegami ze szkolnej ławy. $\mathrm{Z}$ biegiem czasu oba te portale były wielokrotnie modyfikowane, a ich twórcy dodawali nowe funkcje, dając użytkownikom większe możliwości działania (np. oś czasu na Facebooku, przypominająca w pewien sposób pamiętnik, czy też mikroblog na Nasza-Klasa.pl).

Każdy portal społecznościowy można w obecnych czasach uznać za nowoczesne centrum rozrywki, jak również kanał komunikacji. Niewątpliwie najbardziej rozwinięty pod każdym względem jest Facebook. Można zadać więc pytanie, czemu media społecznościowe tak urosły w siłę i czemu są tak istotne w naszym życiu. Na to pytanie najtrafniej odpowiedziała Ewa Krok (2011, s. 50-51), która wyszczególniła sześć kategorii wskazujących na siłę mediów społecznościowych:

1. umożliwiają wyrażanie swoich opinii i poglądów,

2. służą współdzieleniu zasobów (zdjęć, filmów, itp.), 
3. zorientowane są na budowanie i podtrzymywanie relacji międzyludzkich,

4. ukierunkowane są na interakcje w postaci dyskusji i debaty,

5. zaspokajają potrzebę bieżącego informowania i odnoszenia się do aktualności,

6. nastawione są na współtworzenie.

Korzystanie z mediów społecznościowych powodować może również negatywne konsekwencje dla użytkowników. Wśród najpopularniejszych wymienić można:

„1. uzależnienie,

2. modelowanie postaw i zachowań agresywnych,

3. dostęp do treści niebezpiecznych" (Sowa-Behtane 2016, s. 15).

W ramach tych trzech grup Ewa Sowa-Behtane (2016, s. 16-22) szerzej opisuje czyhające zwłaszcza na dzieci i młodzież zagrożenia, do których zalicza:

1. zagrożenia seksualne,

2. zagrożenia psychiczne i intelektualne,

3. zagrożenia moralne i etyczne,

4. zagrożenia społeczne,

5. cyberbulling,

6. uzależnienie od Facebooka.

Najważniejszym według autorów zagrożeniem jest właśnie uzależnienie od Facebooka (bądź też innych portali społecznościowych), ponieważ to przez ten portal mogą być narażeni na kontakt z wymienionymi wyżej zagrożeniami.

\section{UZALEŻNIENIE OD MEDIÓW SPOŁECZNOŚCIOWYCH}

Zanim przejdziemy do omówienia zjawiska uzależnienia od mediów społecznościowych czy też ogólnie Internetu, należy najpierw wyjaśnić samo pojęcie uzależnienia. Zbigniew Zaborowski (2001) uzależnienie traktuje jako

proces bądź jego efekt związany z wytwarzaniem się specyficznego związku między jednostką a jej czynnościami, zachowaniem bądź między jednostką a innymi ludźmi, który charakteryzuje się ograniczeniem pola świadomości, pola decyzyjnego i wyborem często jednej tylko, i to w sposób kompulsywny, alternatywy.

Według Aviela Goodmana (1990, s. 1406) najogólniej uzależnienie traktować należy jako „zbiór relacji między wzorcem zachowania i niektórymi innymi procesami lub aspektami życia człowieka”. Szerzej jednak rozumieć je należy jako 
„proces, za pomocą którego dane zachowanie może być zarówno źródłem gratyfikacji i zapewniać ucieczkę od wewnętrznego dyskomfortu, charakteryzujący się utratą kontroli i kontynuacją pomimo jego istotnych negatywnych skutków".

Jak można zatem zauważyć na podstawie powyższych definicji, uzależnienie jest pewnym procesem zachodzącym w psychice człowieka i mającym wpływ na jego fizyczność oraz zachowania. Podobnego zdania jest Czesław Cekiera (1993), który uważa, że „uzależnienie psychiczne jest to stan psychiczny powstały w wyniku przyjmowania różnych środków uzależniających, przejawiających się różnorodnym stopniem pragnienia przyjmowania tych środków”. Andrew M. Colman (2009, s. 820-821) uważa, iż uzależnienie to:

psychologiczna, czasem fizyczna zależność od substancji, szczególnie w odniesieniu do narkotyków [...], ale także powszechnie stosowanych substancji, takich jak nikotyna, kofeina czy alkohol, charakteryzująca się przymusem przyjmowania danej substancji w celu doświadczenia jej efektów.

Uzależnionym można w takim razie być nie tylko od różnego rodzaju używek, ale również „od kogoś lub czegoś” (Sillamy 1989, s. 316). Z tego też względu należy przyjąć, że może mieć ono charakter zależności fizycznej i/lub psychicznej (por. Chwaszcz, Pietruszka, Sikorski 2005, s. 93). Podobnego zdania jest Barbara Kołłątaj (2013, s. 193), która uważa, że

uzależnienie to złożone zaburzenia zachowania polegające przede wszystkim na wewnętrznym przymusie:

a) ciągłego lub okresowego używania substancji o działaniu psychoaktywnym,

b) ponawianiu wykonywania pewnych czynności,

c) realizacji celów w sposób dezorganizujący funkcjonowanie człowieka w rodzinie, społeczeństwie lub w sposób zagrażający zdrowiu lub życiu osoby uzależnionej.

Analizując przytoczone powyżej podejścia do uzależnienia, zauważyć można, iż człowiek może uzależnić się od innego człowieka, różnych substancji, jak również od czynności (np. stosowanie sprzętu multimedialnego itp.). Anna Andrzejewska (2007, s. 1189) sprowadza to wszystko do jednego stwierdzenia, że uzależnienie to „utrata kontroli nad swoim zachowaniem”. Uważa ona również, iż

w przypadku mediów cyfrowych [w tym mediów społecznościowych - uzup. autorów] można mówić o uzależnieniu wówczas, gdy korzystanie z nich zaczyna przeszkadzać w normalnym życiu, w wykonywaniu pracy, w kontaktach międzyludzkich, kiedy stanowi swoisty substytut rzeczywistego życia. 
Jak wynika z powyższych analiz definicji, uzależnienia mogą być związane nie tylko z substancjami psychoaktywnymi, ale również z wykonywanymi przez człowieka czynnościami. Ta druga kategoria to uzależnienia behawioralne.

Magdalena Rowicka (2015a, s. 6) terminem tym określa „formy zaburzeń (nałogów) nie związanych z przyjmowaniem substancji psychoaktywnych, a z niekontrolowanym wykonywaniem pewnych czynności”. Marcin Marsollek (2012, s. 45) definiuje uzależnienia behawioralne jako uzależnienia polegające na „kompulsywnym, przymusowym wykonywaniu czynności w celu pozbycia się nieznośnego napięcia psychicznego".

Na portalu Wikipedia.pl (www 4) można przeczytać, iż uzależnienia behawioralne, czyli inaczej mówiąc czynnościowe, to „zespół objawów związanych z utrwalonym, wielokrotnym powtarzaniem określonej czynności (lub grupy czynności) w celu uzyskania takich stanów emocjonalnych, jak przyjemność, euforia, ulga, uczucie zaspokojenia".

Zjawiska, do których odnosi się pojęcie uzależnienia behawioralne, pojawiły się „stosunkowo niedawno i są związane z postępem technologicznym i coraz bardziej rozwijającą się cywilizacją" (Marsollek 2012, s. 45). Za twórcę określenia uznawany jest „Otto Fenichel, który po raz pierwszy użył go w swoim dziele The Psychoanalytic Theory of Neurosis" (Lelonek-Kuleta 2014, s. 17). Między innymi $\mathrm{z}$ tego powodu (ale i ze względów metodologicznych) do tej pory uzależnienia behawioralne „nie funkcjonują w żadnej klasyfikacji chorób i zaburzeń, tj. ani w ICD 10, ani DSM-IV" (Rowicka 2015a, s. 6).

Jeden z czołowych włoskich ekspertów w dziedzinie uzależnienia Cesare Guerreschi (2006, s. 24) uzależnienia behawioralne określa mianem „nowych uzależnień”. Według niego ich przedmiotem są przede wszystkim „zachowania i działania akceptowane społecznie”. Magdalena Rowicka (2015a, s. 8) zauważa również, iż jest wiele zachowań potencjalnie uzależniających w życiu każdego człowieka. Wśród nich wymienia m.in.: seks, zakupy, pracę i zdrowe jedzenie. Analizując na ten katalog zachowań, można przekonać się, że trudno zauważyć granicę między pasją a początkami problemu. Z tego też względu można domniemywać, iż „problem zaczyna się, kiedy wykonywanie opisanych zachowań osiąga pewien stopień fiksacji i ma negatywne konsekwencje dla jednostki i jej najbliższego otoczenia”.

Do wymienionych przez Rowicką zachowań mogących uzależniać Bohdan T. Woronowicz (2012, s. 9) dodaje:

narastające w ostatnich latach lawinowo uzależnienie od komputera bądź Internetu (siecioholizm). Wśród uzależnień behawioralnych wyodrębniono jeszcze uzależnienie od technologii (technological addiction), tj. uzależnienie będące skutkiem interakcji człowieka z maszyną (np. z komputerem czy z telefonem). 
Ryszard Poprawa (2012, s. 59) uważa, iż uzależnienia behawioralne związane są silnie z różnego rodzaju zachowaniami nałogowymi, które „ogólnie ujmując, dotyczą tych czynności, które są emocjonalnie angażujące, gdyż wpływają na funkcjonowanie emocjonalne jednostki, dostarczają szybko silnych, chociaż krótkotrwałych gratyfikacji”. Porównując analizy uzależnień czynnościowych do uzależnień od substancji, można zauważyć, podobnie jak Christina Davidson, że „W obydwu rodzajach zaburzeń na poziomie biologicznym biorą udział te same neuroprzekaźniki” (Lelonek-Kuleta 2014, s. 16).

Mariusz Jędrzejko i Agnieszka Taper (2014, s. 13) porównali zmiany, jakie zaszły w życiu osób w wieku od 15 do 50 lat i zauważyli coraz większą powszechność nowych technologii cyfrowych zarówno w życiu osobistym, jak i zawodowym. Proces ten nabiera dopiero tempa i, jak podkreślają autorzy, ,jego kształt i powszechność powinniśmy widzieć w perspektywie urządzeń, jak Google-Glass i smartfon”. Agnieszka Ogonowska (2014, s. 11) nazywa to uzależnieniami medialnymi i uznaje za syndrom „współczesnej silnie stechnologizowanej cywilizacji, w której bezpośrednia komunikacja między ludźmi jest w coraz większym stopniu zastępowana przez kontakty zapośredniczone przez różne technologie".

W obecnych czasach, jak już zostało wspomniane, coraz większym zagrożeniem jest uzależnienie od Internetu oraz oferowanych w nim usług. Pionierem badań nad uzależnieniem od sieci i komputera jest dr Kimberly Young, która

wyróżniła pięć podtypów uzależnienia związanego z komputerem, tj.:

- erotomanię internetową,

- socjomanię internetową,

- uzależnienie od sieci internetowej,

- przeciążenie informacyjne, czyli przymus pobierania informacji,

- uzależnienie od komputera (Woronowicz 2012, s. 12).

Rowicka (2015b, s. 26) uważa, iż „w miarę zgłębiania tematyki uzależnienia od Internetu zaczęły pojawiać się coraz większe wątpliwości dotyczące przede wszystkim przedmiotu uzależnienia - czy jest to komputer czy Internet, czy może wykonywanie konkretnych czynności przy użyciu komputera i Internetu?" Między innymi Shih-Ming Li i Teng-Ming Chung (2006) twierdzą, że Internet sam w sobie nie jest uzależniający, lecz usługi w nim oferowane.

W ostatnich latach coraz częściej mówi się o uzależnieniu od sieci społecznościowych, w tym od Facebooka. Spowodowane jest to przede wszystkim powstawaniem „kolejnych portali społecznościowych oraz szybko rosnącą liczbą osób, które pragną na tych portalach zaistnieć" (Dziewiecki 2011). W przypadku tego 
rodzaju uzależnień można posiłkować się kryteriami przyjętymi między innymi przez Marka Griffithsa (2005):

- zmiana nastroju wynikająca z korzystania z Facebooka,

- zaabsorbowanie Facebookiem,

- ukrywanie przed rodziną i przyjaciółmi ilości czasu spędzonego na korzystaniu z Facebooka,

- tolerancja,

- symptomy odstawienne wynikające z braku dostępu do Facebooka,

- doświadczanie konfliktu psychicznego, interpersonalnego i związanego z zaniedbaniem obowiązków czy porzuceniem hobby na rzecz spędzania czasu na korzystaniu z Facebooka,

- nawrót (Rowicka 2015b, s. 26).

Pionierami w badaniu uzależnienia od Facebooka są Cecile S. Andreassen, Torbjørn Torsheim, Geir S. Brunborg i Ståle Pallesen z Norwegii. Opracowali oni skalę pozwalającą badać poziom uzależnienia od Facebooka (BFAS). Uzasadniając potrzebę tego rodzaju badań, twierdzą, że „ponieważ korzystanie z Facebooka rośnie bardzo szybko, istnieje konieczność przeprowadzenia psychomertycznie solidnej procedury dla oceny możliwego uzależnienia" (Andreasson i inni 2012, s. 503). Po przeprowadzeniu badań na 423 studentach okazało się, że skala może być z powodzeniem stosowana do badania prawdopodobieństwa uzależnienia od Facebooka.

\section{CEL I OPIS BADAŃ}

Głównym celem badań było określenie stopnia oraz możliwości uzależnienia studentów wybranych kierunków i specjalności nauczycielskich od Facebooka. Badania ankietowe przeprowadzone były wśród studentów I roku kierunków pedagogika $(65,67 \%)$ oraz pedagogika specjalna $(34,33 \%)$ studiujących na Wydziale Pedagogiki i Psychologii UMCS. Odbyły się one w maju 2016 roku. Łącznie w badaniach wzięły udział 134 osoby, w tym 128 kobiet (95,52\%) i 6 mężczyzn (4,48\%). Wśród specjalności najliczniejszą grupę stanowią studenci specjalności pedagogika wczesnoszkolna i przedszkolna - 34,33\%. Pozostali studenci wybierali specjalności: opiekuńczo-wychowawcza z terapią pedagogiczną - 31,34\%, resocjalizacja - 23,88\%, oligofrenopedagogika $-6,72 \%$ oraz tyflopedagogika i surdopedagogika - 3,73\%. 
Respondenci byli w wieku $20-21$ lat $(83,43 \%)$ oraz $18-19$ lat $(11,28 \%)$. Badani studenci pochodzili głównie z terenów wiejskich (44,78\%) oraz miast do 50000 mieszkańców (31,34\%). Ponad połowa nie pracuje i nie szuka pracy $(56,72 \%)$, natomiast niespełna $1 / 3$ poszukuje wciąż pracy.

\section{ANALIZA WYNIKÓW BADAŃ}

Wśród ankietowanych najliczniejszą grupę stanowią osoby korzystające z portali społecznościowych - 97,78\%. Jedynie 3 osoby nie posiadają konta na tego typu stronach. Wykres 1 pokazuje wszystkie używane przez respondentów portale społecznościowe.

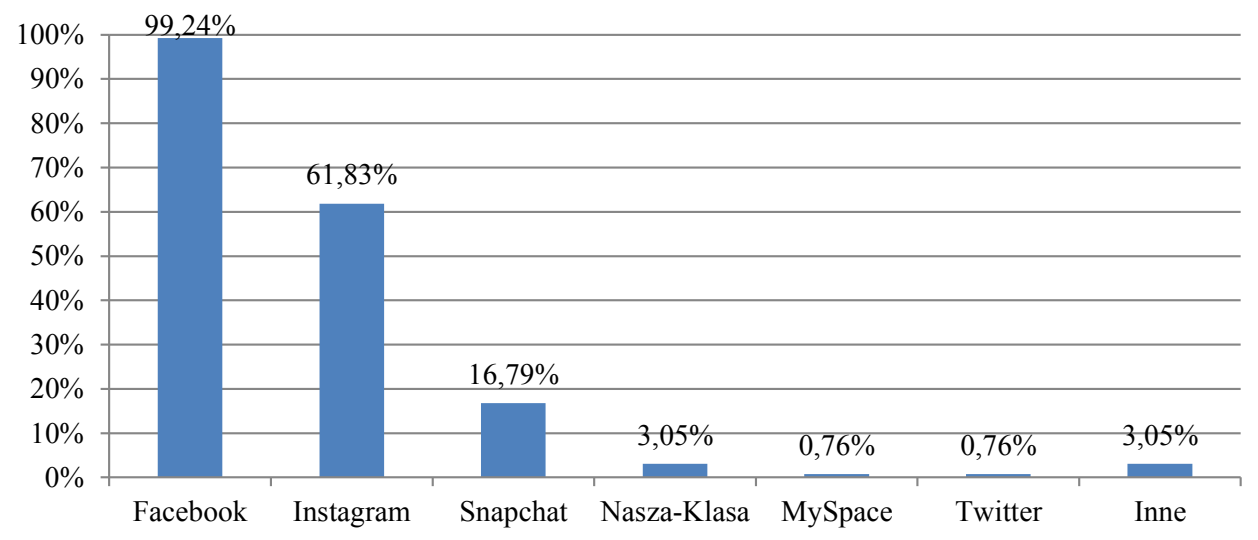

Wykres 1 . Wykorzystywane przez studentów portale społecznościowe

Jak można zauważyć, najliczniej studenci korzystają z Facebooka (99,24\%) oraz Instagrama (61,83\%). Niespełna $1 / 5$ badanych korzysta również ze Snapchata.

Wśród powodów, które skłoniły badanych do założenia konta na portalu społecznościowym, była przede wszystkim ciekawość - 70,99\%. Wykres 2 prezentuje wszystkie odpowiedzi respondentów odnoszące się do powodów utworzenia konta na omawianych portalach. 


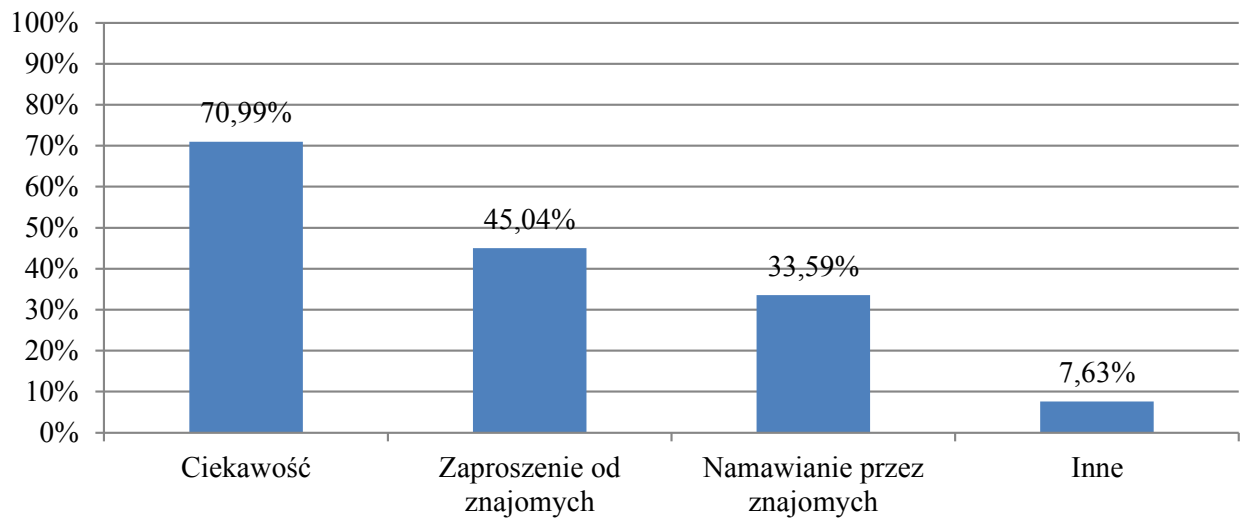

Wykres 2. Powody utworzenia konta na portalu społecznościowym

Dane pokazują, że oprócz ciekawości badani studenci tworzyli konta za namową znajomych $(33,59 \%)$ lub też w odpowiedzi na ich zaproszenie $(45,04 \%)$ wysyłane z konkretnego portalu. Jako inne przyczyny wymieniali przede wszystkim to, iż przez portal społecznościowy (w ramach konkretnej grupy znajomych) umieszczane i wysyłane są materiały ze studiów.

Na pytanie o oczekiwania względem wybranego portalu społecznościowego badani studenci wskazali przede wszystkim utrzymanie kontaktu ze znajomymi - 90,08\%, w dalszej kolejności rozmowy ze znajomymi - 83,21\%. Wykres 3 prezentuje oczekiwania wymieniane przez respondentów.

Utrzymanie kontaktów ze znajomymi

Rozmowy ze znajomymi

Spędzanie wolnego czasu

Nawiązywanie nowych kontaktów

Zamieszczanie zdjęć, filmów, itp.

Odnowienie znajomości

Zaspokojenie ciekawości Inne

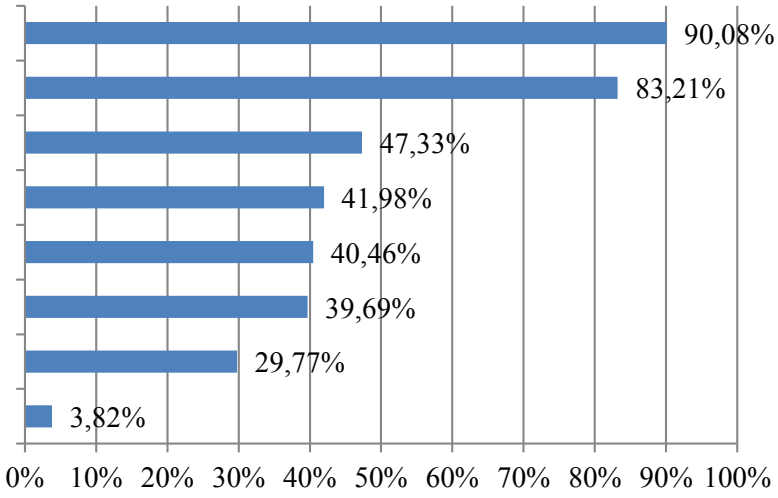

Wykres 3. Oczekiwania wobec portalu społecznościowego

Badani studenci używają portali społecznościowych głównie jako narzędzia do utrzymywania kontaktów ze znajomymi, rówieśnikami i rodziną. Za ich pomocą 
nawiązują również nowe znajomości - 41,98\%. Wiele osób wykorzystuje te portale do zamieszczania różnych materiałów typu: zdjęcia, filmy, muzyka (40,46\%), tyczące się zarówno ich osoby, jak i innych. Blisko połowa badanych wolny czas poświęca na korzystanie z portalu społecznościowego.

Prawie 65\% respondentów loguje się na dowolnym portalu kilka razy dziennie $-64,89 \%$. Pozostałe odpowiedzi udzielone przez studentów przedstawione zostały na wykresie 4.

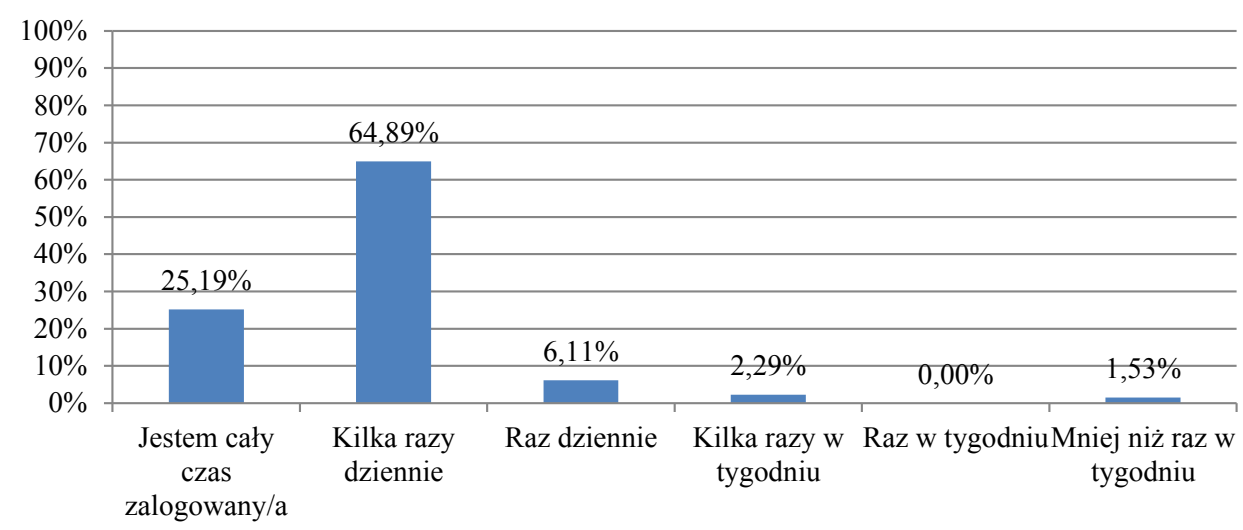

Wykres 4. Częstotliwość korzystania z portalu społecznościowego

Patrząc na powyższe wyniki łatwo można zauważyć, że ponad 1/4 badanych studentów jest non stop zalogowana na wybranym przez siebie portalu społecznościowym. Może to z jednej strony wskazywać na to, że osoby te są uzależnione od tych portali. Z drugiej jednak studenci ci często korzystają ze smartfonów (wykres 5). Wykorzystanie tego rodzaju urządzeń umożliwia im bycie cały czas online. Zdarza się również, iż raz logując się np. na Facebooku, nie wylogowują się dla wygody oraz w celu śledzenia na bieżąco tego, co robią inni. 


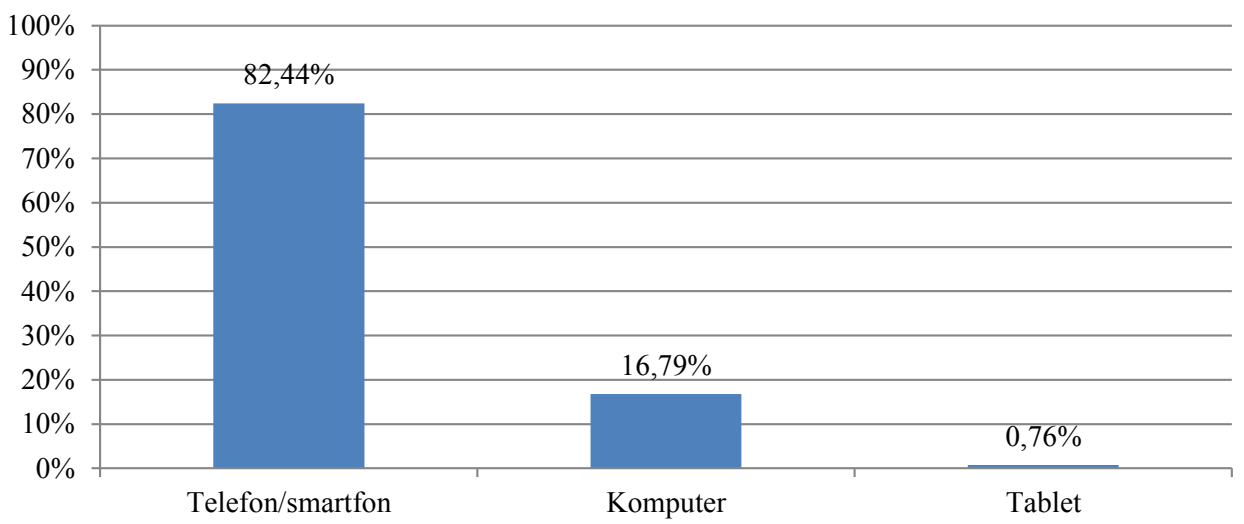

Wykres 5. Urządzenia wykorzystywane do logowania się na portalu społecznościowym

Dane zaprezentowane na powyższym wykresie wskazują, że oprócz telefonu/ smartfona badani studenci do korzystania z portali społecznościowych używają komputera. Jest ich jednak tylko 16,79\%. Jak sami tłumaczą, spowodowane jest to głównie małą mobilnością komputera czy też laptopa w porównaniu do smartfonów, z którymi się prawie nie rozstają.

Wśród aktywności wykonywanych podczas pracy z portalem społecznościowym (wykres 6) znajdują się przede wszystkim różnego rodzaju formy kontaktu z innymi członkami społeczności (93,13\%). Dla 2,29\% studentów ważnym aspektem korzystania z tego rodzaju portalów jest szukanie przyjaciół sprzed lat. Warty uwagi jest fakt, iż studenci sprawdzają informacje o sobie, które mogą umieszczać inni. Tego typu zachowania mogą świadczyć o narcystycznej naturze niektórych członków społeczności akademickiej lub obawy przed oceną, ośmieszeniem. Oprócz tego mogą również dowodzić, iż użytkownicy chcą kontrolować sytuację wokół siebie, sprawdzać swoją wartość oraz mają potrzebę bycia pochwalonym przez innych.

Ważnym aspektem badania ryzyka uzależnienia od Facebooka jest również spojrzenie na to, jak studenci spędzają wolny czas. Wyniki zaprezentowane zostały na wykresie 7. Z udzielonych przez badanych studentów odpowiedzi wynika, że najczęściej w czasie wolnym spotykają się ze znajomymi - 80,15\%. W trakcie spędzania wolnego czasu aż 57,25\% respondentów korzysta z portali społecznościowych. Jest to duża liczba badanych, zwłaszcza jeśli odniesiemy te wyniki do częstotliwości logowania się na konta. Nie mniej osób (50,38\%) woli spędzać czas z rodziną. Ponad $1 / 3$ studentów oprócz wymienionych aktywności woli dodatkowo oglądać telewizję, natomiast 9,16\% - grać w gry komputerowe. Należy zauważyć, iż wiele osób łączy powyższe aktywności np. przez wspólne oglądanie telewizji z rodziną, niejednokrotnie równocześnie grając na komputerze lub korzystając np. z Facebooka. 


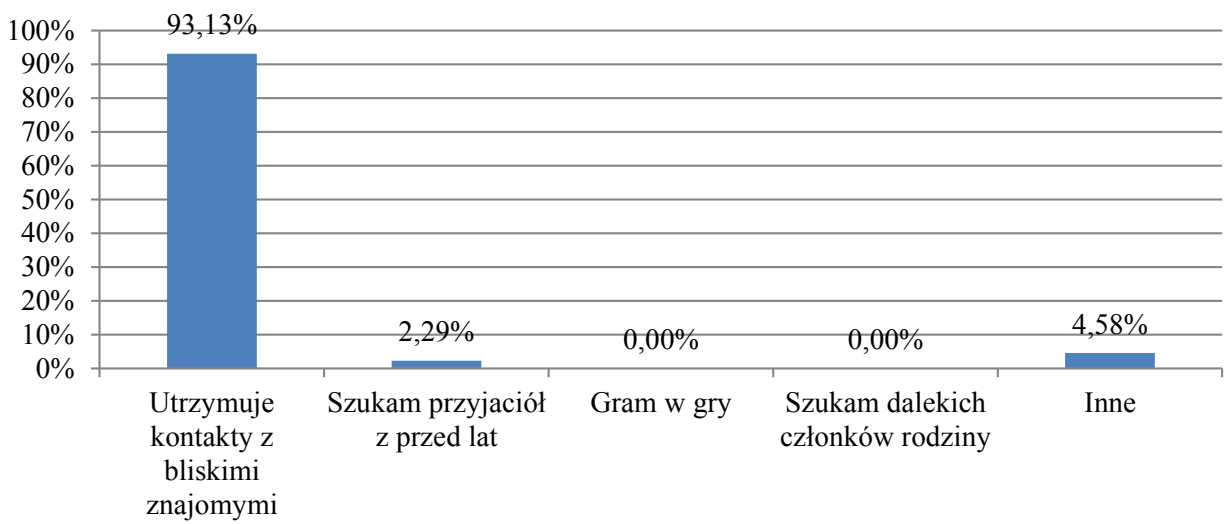

Wykres 6. Aktywności studentów na portalach społecznościowych

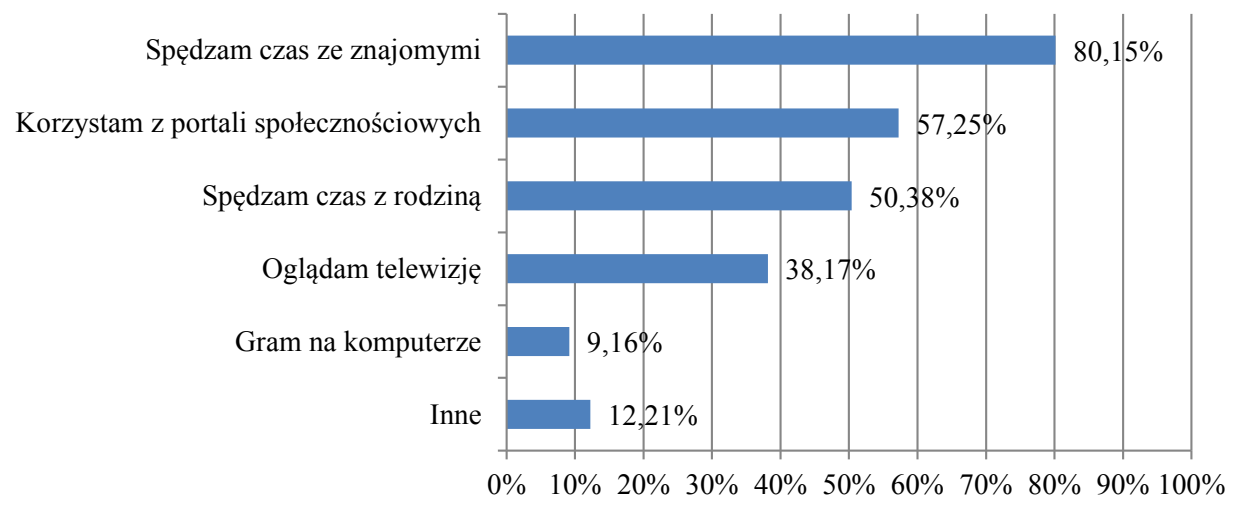

Wykres 7. Formy spędzania wolnego czasu studentów

Wśród innych aktywności respondenci wymieniają jazdę na rowerze/rolkach, czytanie książek lub realizowanie pasji.

Patrząc na opisane do tej pory wyniki badań, zauważyć można, iż jest wiele elementów mogących wskazywać na pojawienie się problemu nadmiernego korzystania z sieci społecznościowych. Jak już zostało wcześniej wspomniane, pionierami w badaniu tego zjawiska są Andreassen, Torsheim, Brunborg i Pallesen z Wydziału Nauk Psychologicznych Uniwersytetu w Bergen w Norwegii. W opracowanej przez nich skali pierwotnie znajdowało się 18 twierdzeń podzielonych na 6 grup: istotność, tolerancję, zmianę nastroju, nawroty, odzwyczajanie się oraz konflikt. Jednakże w toku analiz jakościowo-ilościowych przy zastosowaniu metod statystycznych wyselekcjonowali oni 6 twierdzeń (po jednym z każdej grupy). Na ich 
podstawie można określić, czy istnieje ryzyko uzależnienia od Facebooka. Jeśli na co najmniej 4 twierdzenia osoba badana odpowiedziała „często” lub „bardzo często", może to sugerować problem z uzależnieniem.

W analizowanych tu badaniach autorzy wykorzystali wszystkie 18 twierdzeń i kazali studentom wskazać częstotliwość występowania danego czynnika. Spowodowane było to chęcią przyjrzenia się, jaki stosunek mają badani do wszystkich twierdzeń. Zbiorcze wyniki przedstawione zostały w tabeli 1 .

$\mathrm{Z}$ prezentowanych $\mathrm{w}$ tabeli 1 danych wynika, że dla pierwszej grupy czynników najliczniejszą grupę stanowią studenci, którzy bardzo rzadko myślą o tym, w jaki sposób mogą więcej wolnego czasu poświęcać na korzystanie z Facebooka (48,09\%). W dalszej kolejności rzadko myślą o: ostatnich wydarzeniach na Facebooku (38,93\%), możliwości częstszego korzystania z tej sieci społecznościowej (37,40\%) oraz planowaniu dalszych aktywności (36,64\%). Godny uwagi jest fakt, że w przypadku wybranego do ostatecznej wersji narzędzia twierdzenia jedynie 10 osób określiło, iż często myślą i planują, co będą robić na Facebooku. Jednakże niepokojącym wydaje się, że łącznie aż 13\% badanych często lub bardzo często myśli o tym, co wydarzyło się ostatnio na tym portalu. Tego rodzaju zachowanie przekładać się może negatywnie na inne realizowane przez nich zadania, ponieważ ich myśli krążą wokół wirtualnej rzeczywistości, a nie realnego świata.

Z analizy drugiej grupy czynników składających się na skalę BFAS, czyli tolerancja, wynika, iż najliczniejszą grupę stanowią studenci bardzo rzadko mający potrzebę coraz częstszego korzystania z Facebooka, aby mieć z tego przyjemność - 47,33\%, zaś $1 \frac{1}{3}$ badanych stanowią osoby rzadko czujące potrzebę częstszego korzystania z tego portalu dla zaspokajania przyjemności. Wśród studentów, którzy spędzają więcej czasu, niż pierwotnie zakładali, jest 30,53\% czasami mających taką sytuację. Natomiast bardzo rzadko (30,53\%) oraz czasami $(29,77 \%)$ badani studenci odczuwają coraz większą ochotę korzystania z Facebooka w miarę poświęcania mu czasu i uwagi. Należy tu zauważyć również, iż aż 36,64\% łącznie stanowią osoby często lub bardzo często spędzające więcej czasu, korzystając z portalu społecznościowego, niż sobie to pierwotnie zakładały. Spowodowane może to być chociażby tym, że zarówno przez rodziców, jak i nauczycieli nie zostało u nich wykształcone sztywne stawianie sobie granic i staranie się, by ich nie przekraczać. 


\begin{tabular}{|c|c|c|c|c|c|c|c|c|c|c|c|c|c|c|c|c|c|c|}
\hline \multirow{2}{*}{ 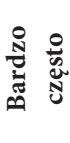 } & $\therefore$ & $\begin{array}{l}8 \\
0 \\
0\end{array}$ & $\begin{array}{c}0 \\
\infty \\
\infty\end{array} \mid$ & $\left|\begin{array}{l}\infty \\
2 \\
\mathfrak{y}\end{array}\right|$ & $\begin{array}{l}0 \\
0 \\
-1\end{array}$ & $\stackrel{8}{\circ}$ & $\begin{array}{l}0 \\
\stackrel{2}{2} \\
-1\end{array}$ & $\begin{array}{l}\stackrel{0}{2} \\
\stackrel{0}{0}\end{array}$ & $\begin{array}{l}\stackrel{0}{0} \\
0\end{array}$ & ते & $\begin{array}{l}2 \\
2 \\
0\end{array}$ & $\begin{array}{c}\hat{n} \\
-\rightarrow \\
-1\end{array}$ & $\begin{array}{c}0 \\
\text { Sn } \\
-1\end{array}$ & $\begin{array}{l}8 \\
0 \\
0\end{array}$ & 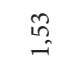 & $\begin{array}{c}0 \\
\infty \\
\hat{m}\end{array} \mid$ & \begin{tabular}{l}
2 \\
\multirow{0}{0}{}
\end{tabular} & $\begin{array}{l}8 \\
0 \\
0\end{array}$ \\
\hline & $\mathbf{z} \mid 0$ & 0 & in & $=$ & $\sim$ & 0 & $\sim$ & -1 & -1 & $m$ & -1 & $N$ & $v$ & 0 & $\sim$ & in & - & 0 \\
\hline \multirow{2}{*}{ 怤 } & 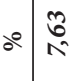 & 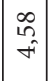 & $\begin{array}{l}0 \\
a \\
a\end{array}$ & $\mid \begin{array}{l}0 \\
\stackrel{n}{0} \\
\sim\end{array}$ & $\begin{array}{l}\hat{b} \\
\hat{9}\end{array}$ & 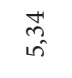 & 7 & $\vec{\sigma}$ & $\tilde{\alpha}$ & 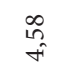 & $\underset{\infty}{+}$ & $\begin{array}{l}\infty \\
\infty \\
0\end{array}$ & $\frac{?}{a}$ & $\begin{array}{l}\hat{\infty} \\
\hat{0}\end{array}$ & $\begin{array}{l}\overrightarrow{\mathrm{N}} \\
\tilde{\simeq}\end{array}$ & $\begin{array}{c}\alpha \\
\alpha \\
\alpha\end{array}$ & $\stackrel{\stackrel{f}{+}}{=}$ & సે \\
\hline & $\mathrm{z} \mid \mathrm{Q}$ & 6 & $\approx$ & $\vec{m}$ & $\Xi$ & $n$ & $\infty$ & $\infty$ & $m$ & 6 & $=$ & $a$ & $\approx$ & $a$ & 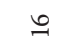 & 2 & 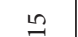 & $m$ \\
\hline \multirow{2}{*}{ 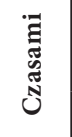 } & $\therefore \begin{array}{l}02 \\
20\end{array}$ & 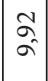 & $\begin{array}{l}\overrightarrow{0} \\
\hat{n}\end{array}$ & $\mid \begin{array}{l}n \\
\hat{n} \\
0 \\
0 \\
0\end{array}$ & $\begin{array}{l}\hat{N} \\
\hat{N}\end{array}$ & $\underset{m}{\stackrel{n}{m}}$ & $\begin{array}{l}\infty \\
\stackrel{1}{\beth}\end{array}$ & $\begin{array}{l}\text { O } \\
+\infty\end{array}$ & $\begin{array}{l}\stackrel{f}{\ddagger} \\
=\end{array}$ & 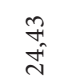 & $\begin{array}{l}\infty \\
\infty \\
2\end{array}$ & $\left|\begin{array}{l}\infty \\
0 \\
2 \\
-1\end{array}\right|$ & $\begin{array}{l}\overline{6} \\
8\end{array}$ & $\begin{array}{l}m \\
0 \\
0 \\
0\end{array}$ & $\stackrel{\text { जे }}{\text { जे }}$ & $\left|\begin{array}{l}n \\
1 \\
0 \\
0\end{array}\right|$ & $\begin{array}{l}\stackrel{0}{0} \\
\stackrel{\sim}{\hat{n}}\end{array}$ & مू \\
\hline & Z & $\cong$ & $\infty$ & 우 & बे & $\infty$ & $\approx$ & $=$ & 20 & $\tilde{m}$ & \% & 20 & $\hat{\approx}$ & $\vec{d}$ & $m$ & 워 & $\vec{m}$ & $\underline{a}$ \\
\hline \multirow{2}{*}{ 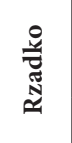 } & $\therefore \mid \begin{array}{l}0 \\
0 \\
0 \\
0\end{array}$ & $\mid \begin{array}{l}0 \\
\text { an } \\
\text { ñ }\end{array}$ & $\begin{array}{c}\tilde{2} \\
\alpha \\
\tilde{n}\end{array}$ & $\begin{array}{l}0 \\
\stackrel{2}{0} \\
\end{array}$ & 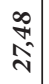 & مे & $\begin{array}{l}10 \\
8 \\
2\end{array}$ & $\begin{array}{c}\hat{m} \\
\hat{\sim}\end{array}$ & 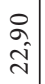 & $\begin{array}{l}\stackrel{0}{0} \\
\stackrel{2}{=}\end{array}$ & $\begin{array}{l}20 \\
2 \hat{2}\end{array}$ & $\left|\begin{array}{l}n \\
\hat{n} \\
0 \\
0 \\
n\end{array}\right|$ & $\frac{2}{\hat{v}}$ & $\begin{array}{l}\infty \\
\stackrel{2}{\Omega}\end{array}$ & $\stackrel{\vec{\omega}}{\hat{n}}$ & $\begin{array}{c}\tilde{m} \\
\infty \\
\infty \\
\sim\end{array}$ & $\begin{array}{l}\text { ڤे } \\
\text { तิ }\end{array}$ & 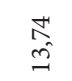 \\
\hline & z $\mid \stackrel{\infty}{\sim}$ & के & in & $\ddot{\sim}$ & i & F & i & $\stackrel{\infty}{\sim}$ & i & $\tilde{\sim}$ & m & 와 & $m$ & $\stackrel{2}{\sim}$ & $m$ & I & i & $\stackrel{\infty}{\infty}$ \\
\hline \multirow{2}{*}{ 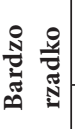 } & 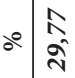 & 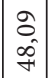 & $\begin{array}{l}\infty \\
0 \\
2 \\
2\end{array} \mid$ & $\begin{array}{l}\hat{\lambda} \\
\hat{n} \\
\end{array}$ & $\begin{array}{l}n \\
0 \\
0 \\
0\end{array}$ & $\begin{array}{l}\stackrel{m}{N} \\
\stackrel{+}{+}\end{array}$ & $\begin{array}{l}15 \\
2 \\
15\end{array}$ & $\begin{array}{l}0 \\
\text { nీ} \\
\hat{b}\end{array}$ & 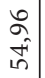 & $\stackrel{n}{n}$ & $\begin{array}{c}5 \\
80 \\
18\end{array}$ & $\begin{array}{c}\infty \\
\stackrel{7}{7} \\
-1\end{array}$ & $\begin{array}{l}5 \\
m^{2}\end{array}$ & $\begin{array}{l}\text { ô } \\
\text { ô } \\
i n\end{array}$ & $\begin{array}{l}\infty \\
\infty \\
i n\end{array}$ & \begin{tabular}{c}
2 \\
\multirow{2}{*}{} \\
$\mathrm{N}$ \\
$\mathrm{m}$
\end{tabular} & $\begin{array}{l}\tilde{Z} \\
\vec{F}\end{array}$ & $\begin{array}{l}\text { L } \\
\text { ti }\end{array}$ \\
\hline & z के & 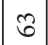 & $\stackrel{2}{\sim}$ & กิ & 아 & $\widetilde{\sigma}$ & $\stackrel{\infty}{\wedge}$ & $\infty$ & $N$ & $\hat{\sigma}$ & के & in & in & 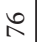 & f & के & in & ล̆ \\
\hline \multirow[t]{3}{*}{ Z o } & 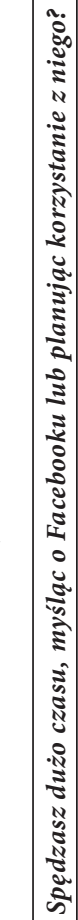 & 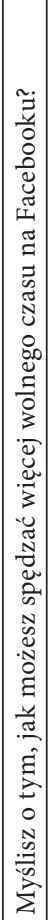 & 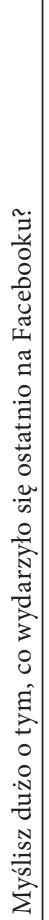 & 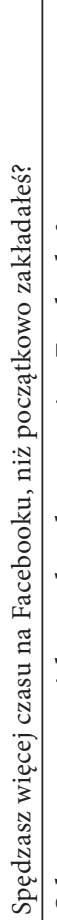 & 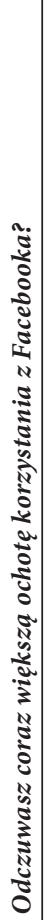 & 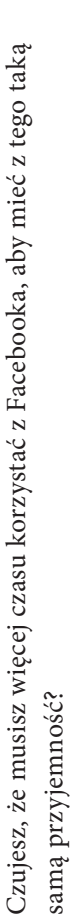 & 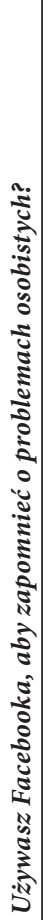 & 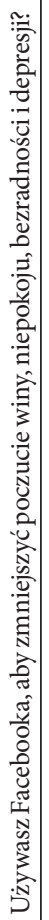 & 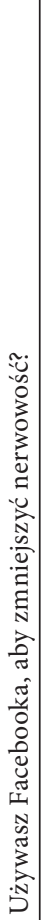 & 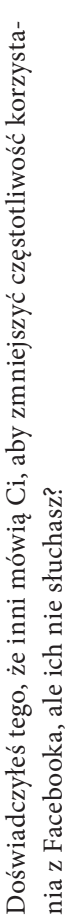 & 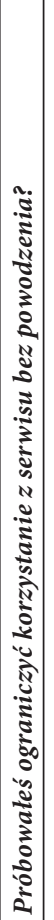 & 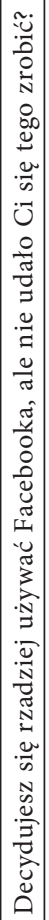 & 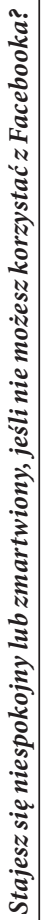 & 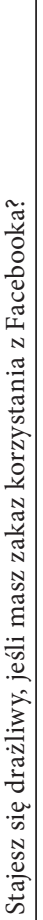 & 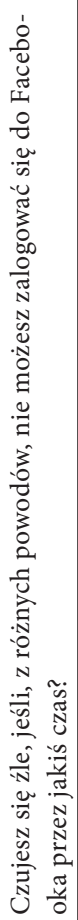 & 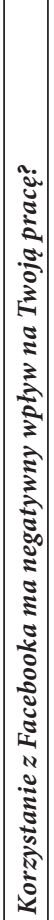 & 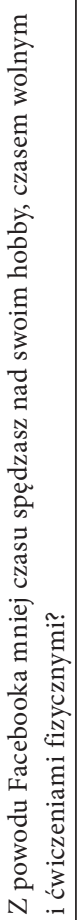 & 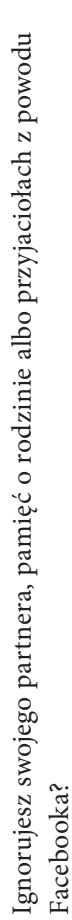 \\
\hline & $\star$ & $\mathrm{v}$ & $m$ & + & in & 6 & $\star$ & $\infty$ & $a$ & & $\stackrel{\star}{=}$ & $\approx$ & $\stackrel{\star}{=}$ & $\Xi$ & $\stackrel{20}{7}$ & t. & $=$ & $\stackrel{\infty}{\rightarrow}$ \\
\hline & \multicolumn{3}{|c|}{ g̨soułołs } & \multicolumn{3}{|c|}{ 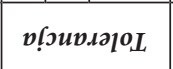 } & \multicolumn{3}{|c|}{$\begin{array}{l}\text { n!o.ıาsvu } \\
\text { вир!นuZ }\end{array}$} & \multicolumn{3}{|c|}{ Кос.ми } & \multicolumn{3}{|c|}{ 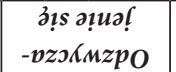 } & \multicolumn{3}{|c|}{ ту!цfиоу } \\
\hline
\end{tabular}


W przypadku trzeciej grupy czynników najliczniej reprezentowane są osoby, które bardzo rzadko korzystają z portalu społecznościowego do radzenia sobie z poczuciem winy, niepokoju, bezradnością i depresją - 63,36\%. Również bardzo rzadko studenci używają Facebooka w celu zapomnienia i ucieczki od problemów osobistych - 59,54\% oraz aby zmniejszyć nerwowość - 54,96\%. Warto tu zauważyć, iż nieliczne, a wręcz pojedyncze osoby często lub bardzo często wykorzystują Facebooka, aby radzić sobie $\mathrm{z}$ wybranymi problemami i zmianami nastroju. Jest to pokrzepiające, ponieważ ucieczka w wirtualny świat nie rozwiąże tych problemów, jedynie może je nasilić. Znacznie lepszym rozwiązaniem jest rozmowa z bliskimi (znajomymi) lub specjalistą.

Analiza czwartej grupy czynników, nazwanej ogólnie nawroty, wykazała, podobnie jak poprzednia, że najliczniejszą grupę stanowią osoby bardzo rzadko i rzadko doświadczające tego zjawiska. 51,15\% badanych bardzo rzadko nie słucha innych osób zwracających im uwagę, aby zmniejszyli częstotliwość korzystania z Facebooka, zaś 45,04\% respondentów bardzo rzadko zdarza się nie zapanować nad korzystaniem z portalu społecznościowego. Również bardzo rzadko zdarza się, że studenci decydują się zmniejszyć częstotliwość korzystania z Facebooka i im się to nie udaje $(41,98 \%)$. Porównywalnie do poprzedniej grupy czynników studenci często i bardzo często stykają się z sytuacjami nawrotów.

W przypadku piątej grupy czynników (odzwyczajanie się) okazało się, że najbardziej liczna jest grupa osób, które bardzo rzadko stają się drażliwe, gdy mają zakaz korzystania z Facebooka - 58,02\%. Równie rzadko studenci wykazują zwiększenie niepokoju, jeśli nie korzystają z Facebooka z własnej woli - 43,51\%. Ponad $1 / 3$ ankietowanych również bardzo rzadko czuje się źle, jeśli nie mogą zalogować się na ten portal. Niestety niepokojące jest to, że łącznie aż 13,74\% stanowią osoby często i bardzo często czujący się źle, gdy nie mogą zalogować się na Facebooka. Niewiele mniej studentów często i bardzo często jest niespokojna lub zmartwiona, jeśli nie korzysta z Facebooka - 10,69\%.

Analiza ostatniej, szóstej grupy (konflikt) wykazała, iż najliczniejszą grupę (aż $74,05 \%)$ stanowią studenci bardzo rzadko ignorujący zaistniałe konflikty z partnerem, pamięć o rodzinie, znajomych z powodu Facebooka. Ponad $41 \%$ badanych bardzo rzadko spędza czas na Facebooku, zamiast zająć się swoim hobby czy też aktywnością fizyczną. Niewiele ponad $1 / 3$ studentów również bardzo rzadko zauważa, aby ich aktywność na portalu negatywnie odbijała się na pracy czy też nauce. Mimo tak dużego odsetka osób bardzo rzadko doświadczających sytuacji konfliktowych spowodowanych przez korzystanie Facebooka aż 13,74\% badanych zauważa, iż ich aktywność w wirtualnym świecie ma negatywny wpływ na pracę i naukę. Niewiele mniej osób uznało, że często lub bardzo często (łącznie 12,21\%) przez Facebooka mniej czasu poświęca na hobby i ćwiczenia fizyczne. Taki stan 
rzeczy powinien być dla tych osób alarmujący, ponieważ aktywność w świecie wirtualnym ma już bezpośredni, do tego negatywny, wpływ na ich realne życie. Przełożyć się to może na problemy w pracy/szkole, jak również na późniejsze relacje rodzinne i partnerskie.

Z przeprowadzonej analizy 6 twierdzeń, które według naukowców z Bergen wskazywać mogą na uzależnienie od Facebooka (wykres 8), widać, że większość studentów na żadne z nich nie udzieliła odpowiedzi „często” lub „bardzo często”. Zgodnie z wytycznymi do kwestionariusza takie osoby nie mają żadnych problemów związanych z uzależnieniem od tego portalu.

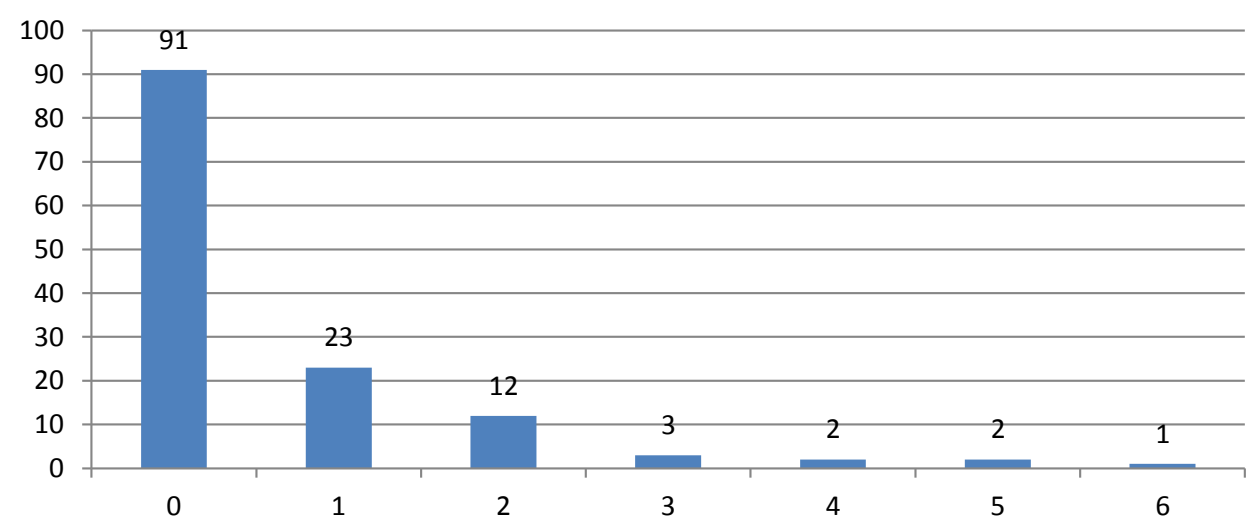

Wykres 8. Liczba osób, które w skali BFAS zaznaczyły odpowiedzi „często” lub „bardzo często”

0 - 6 - liczba twierdzeń zaznaczonych przez respondentów na poziomie „często” lub „bardzo często”

Aby można było mówić o uzależnieniu danej osoby od Facebooka, musi ona zaznaczyć co najmniej 4 twierdzenia na poziomie często lub bardzo często. Przyjmując takie założenia, można stwierdzić, że spośród 134 badanych osób 5 z nich może być uzależnionych od tego portalu społecznościowego. Należy tu również zauważyć, że kolejne 3 osoby są na granicy, ponieważ tylko jedna odpowiedź dzieli je od zakwalifikowania się do grupy uzależnionych od Facebooka.

Odnosząc te dane do liczby osób, które są non stop zalogowane lub też kilka razy dziennie logują się na Facebooka bądź inny portal społecznościowy, można stwierdzić, że otrzymane wyniki dobrze rokują. Liczba osób na poziomie $25 \%$, którzy są ciągle online, sugerować by mogła problem u tych osób. Jednakże spośród nich jedynie 2 osoby są uzależnione od Facebooka. Oczywiście jest pocieszające, że mimo dużej ilości czasu spędzanego na Facebooku badani studenci nie są uzależnieni na chwilę obecną od tego portalu społecznościowego. 


\section{PODSUMOWANIE}

Z przeprowadzonych badań wynika, że jedynie kilku studentów może mieć problemy z uzależnieniem od Facebooka. Podobna sytuacja może być z użytkownikami innych portali społecznościowych, jednak aby to stwierdzić, należałoby użyć innych narzędzi diagnostycznych.

Jak można było się domyślać, najwięcej studentów korzysta z Facebooka. Jest to zrozumiałe, gdy spojrzymy na ogólnoświatowe statystyki użytkowników sieci. Drugim co do liczebności użytkowników portalem jest Instagram. Takie zainteresowanie obydwoma portalami można uzasadnić tak, jak to robią sami badani - ciekawością lub chęcią utrzymania kontaktów z innymi. Można to też tłumaczyć tym, że użytkownicy portali społecznościowych chcą dzielić się sobą z innymi i liczyć na pozytywne komentarze dotyczące swojej osoby. Podkreśla to również Melosik (2013, s. 111), który w swoim artykule zauważa, że prezentowanie siebie przez portal społecznościowy pozwala na podwyższenie własnej samooceny.

Należy również zwrócić uwagę na to, iż powszechność stosowania przez studentów smartfonów wraz z mobilnym dostępem do Internetu ułatwia im bycie cały czas online. Umożliwia im to również, niezależnie od sytuacji, dzielenie się ze znajomymi m.in. zdjęciami oraz przemyśleniami tak, aby na bieżąco mogli śledzić ich dokonania. Niestety może to również powodować, że czas wolny poświęcać będą na korzystanie z portali społecznościowych, a nie np. na realizowanie swoich pasji.

\section{LITERATURA}

Andreassen C. S., Torsheim T., Brunborg G. S., Pallesen S., 2012, Development of a Facebook Addiction Scale. "Psychological Reports", vol. 110, no 2.

Andrzejewska A., 2007, Uzależnienie od mediów cyfrowych. W: Encyklopedia pedagogiczna XXI wieku. Warszawa, Wydawnictwo Akademickie Żak.

Boyd D. M., Ellison N. B., 2007, Social Network Sites: Definition, History and Scholarship. "Journal of Computer-Mediated Communication", no 13.

Cekiera Cz., 1993, Psychoprofilaktyka uzależnień oraz terapia i resocjalizacja osób uzależnionych. Lublin, Wydawnictwo KUL.

Chwaszcz J., Pietruszka M., Sikorski D., 2005, Media. Lublin, Wydawnictwo KUL, Gaudium.

Colman A. M., 2009, Słownik psychologii. Warszawa, PWN.

Doctorow C., Dornfest R., Johnson J. S., Powers S., Trott B., Trott M. G., 2003, Blogging. Przewodnik. Warszawa, Wydawnictwo RM. 
Dziewiecki M., 2011, Portale społecznościowe, czyli fikcyjne więzi, opublikowano: https://opoka.org.pl/biblioteka/X/XK/md_portales.html [dostęp: 29.04.2016].

Fabianiak-Czerniak K., 2012, Internetowe media społecznościowe jako narzędzie public relations. W: K. Kubiak (red.), Zarządzanie w sytuacjach kryzysowych niepewności. Warszawa, Wyższa Szkoła Promocji.

Goodman A., 1990, Addiction: Definition and Implications. "British Journal of Addiction", no 85.

Griffiths M. D., 2005, A „Components” Model of Addiction Within a Biopsychosocial Framework. "J. Subst. Use", no 10.

Guerreschi C., 2006, Nowe uzależnienia. Kraków, Wydawnictwo Salwator.

Jędrzejko M., Taper A., 2014, Uzależnienia behawioralne (człowiek i technologie cyfrowe).

W: Skwarek B., Wulbach E., Lewicka I. (red.), Patologie i uzależnienia (wybrane problemy teorii i praktyki). Warszawa-Łódź, Studio Poligraficzne Edytorka.

Kołłątaj B., Szakuła J., Kołłątaj W., Wrzołek K., Karwat I. D., 2013, Problem uzależnienia od Internetu wśród uczniów szkół ponadpodstawowych w Lublinie. "Journal of Health Sciences", nr 3(5).

Kotyśko M., Izdebski P., Michalak M., Andryszak P., Pluto-Prądzyńska A., 2004, Nadmierne korzystanie z sieci społecznościowych. „Alkoholizm i Narkomania”, t. 27, nr 2 .

Kowalska M., 2013, Funkcjonalność mediów społecznościowych jako siedem boków plastra miodu. „ACTA Universitatis Nicolai Copernici. Zarządzanie”, z. 413.

Krok E., 2011, Media społecznościowe elementem system zarządzania wiedza w firmie. „Zeszyty Naukowe Uniwersytetu Szczecińskiego. Studia Informatica”, nr 28.

Lelonek-Kuleta B., 2014, Uzależnienia behawioralne - podstawy teoretyczne. W: J. Jarczyńska (red.), Uzależnienia behawioralne i zachowania problemowe młodzieży. Teoria Diagnoza Profilaktyka Terapia. Bydgoszcz, Wydawnictwo UKW.

Li S. M., Chung T. M., 2006, Internet Function and Internet Addictive Behaviour. "Computers in Human Behavior", no 22(6).

Łopacińska K., 2004, Social media w zorganizowanej komunikacji marketingowej. „Marketing i Rynek”, nr 12.

Marsollek M., 2012, Wnioski i rekomendacje wynikajace z konferencji. W: V. SkrzypulecPlinta, B. T. Woronowicz, B. Wojewódzka, M. Marsollek (red.), Wolni od uzależnień behawioralnych. Opole, Krajowe Biuro ds. Przeciwdziałania Narkomanii.

Melosik Z., 2013, Facebook i społeczne konstrukcje narcyzmu (o tożsamości zamkniętej w celi wizerunku). „Studia Edukacyjne”, nr 26.

Ogonowska A., 2014, Uzależnienia medialne, czyli o patologicznym wykorzystaniu mediów. Kraków, Wydawnictwo Edukacyjne.

Poprawa R., 2012, Problematyczne używanie Internetu - symptomy i metoda diagnozy. Badania wśród dorastajacej młodzieży. „Psychologia Jakości Życia”, t. 11, nr 1. 
Rowicka M., 2015a, Uzależnienia behawioralne. Terapia i profilaktyka. Warszawa, Ministerstwo Zdrowia, Krajowe Biuro ds. Przeciwdziałania Narkomanii.

Rowicka M., 2015b, Uzależnienie od Facebooka?. „Świat Problemów”, nr 11(274).

Sillamy N., 1989, Słownik psychologii. Wrocław, Wydawnictwo Książnica.

Sowa-Behtane E., 2016, Konsekwencje aktywności na portalach społecznościowych (na przykładzie Facebooka). "World Journal of Theoretical and Applied Sciences", nr 1(4):

Bezpieczeństwo dzieci i młodzieży w przestrzeni wirtualnej - teoria i praktyka". Strykowska J., 2012, Znaczenie mediów społecznościowych w procesie komunikowania i uczenia się. W: W. Strykowski, S. Dylak (red.), Media, Edukacja, Kultura. W strone edukacji medialnej. Poznań-Rzeszów, PTTiME.

Woronowicz B. T., 2012, Uzależnienia behawioralne, ze szczególnym uwzględnieniem uzależnienia od komputera i sieci, od pracy oraz zakupów. Diagnozowanie i leczenie. W: V. Skrzypulec-Plinta, B. T. Woronowicz, B. Wojewódzka, M. Marsollek (red.), Wolni od uzależnień behawioralnych. Opole, Krajowe Biuro ds. Przeciwdziałania Narkomanii.

Zaborowski Z., 2001, Problemy psychologii życia. Warszawa, Wydawnictwo Akademickie Żak.

\title{
NETOGRAFIA
}

www 1 - www.oxforddictionaries.com/definition/english/social-media [dostęp: 22.05.2016].

www 2 - whatis.techtarget.com/definition/social-media [dostęp: 22.05.2016].

www 3 - www.oxforddictionaries.com/definition/english/social-network [dostęp:

22.05.2016].

www 4 - pl.wikipedia.org/wiki/Uzależnienie_behawioralne [dostęp: 06.07.2016].

\section{THE RISK OF DEPENDENCE OF STUDENTS ON SOCIAL MEDIA ON THE EXAMPLE OF FACEBOOK}

\begin{abstract}
This paper is devoted to the issue of behavioral addictions associated with social media. The first part describes the phenomenon of social media. There were explained the notions of addiction and behavioral addiction on the example of Facebook. The second part presents the results of the survey, the aim of which was to diagnose the risk of dependence on Facebook. The obtained results show that only a few of the students may be dependent on this medium.
\end{abstract}

Keywords: addiction, Facebook, social media, behavioral addiction 